\title{
Epidemiological Aspects of Head Lice in Children Attending Day Care Centres, Urban and Rural Schools in Uberlândia, Central Brazil
}

\author{
Raquel Borges, Júlio Mendes ${ }^{+}$
}

\author{
Núcleo de Imunologia, Microbiologia e Parasitologia, Universidade Federal de Uberlândia, Caixa Postal 593, 38400-902 \\ Uberlândia, MG, Brasil
}

From November 1996 to March 2000, a total of 884 children between 0 and 15 years, from 11 institutions including day care centres, public urban and public rural schools in Uberlândia, State of Minas Gerais, central Brazil, were examined for head louse infestation. Children's sex, race, age and some hairs characteristics were shown to be associated to parasite infestation. A prevalence rate of $35 \%$ was found and the highest rates were observed in black, female children, with long, dark, wavy hairs. Hairs density and thickness did not seem to influence significantly the distribution of this pediculosis in Uberlândia's schoolchildren. Differences observed between the prevalence rates of head lice in children from the urban institutions suggest there is a greater epidemiological heterogeneity in this group when compared to the rural schoolchildren.

Key words: head louse - Pediculus capitis - epidemiology - Central Brazil

The head louse, Pediculus capitis (De Geer, 1778) (Anoplura: Pediculidae) is transmitted mainly through physical contact. Symptoms associated to the infestation are constant itching and scalp irritation. When the ectoparasite is associated with poor social conditions and inadequate diet, the infestation may even lead to anaemia (Linardi et al. 1988).

Head lice are a public health problem in various parts of the world (Ewasechko 1981, Kwaku-Kpikpi 1982, Courtiade et al. 1993, Chouela et al. 1997), including in Brazil (Linardi et al. 1989, Madureira 1991) and may be found in people of all ages. However, school age children are more likely to be infested (Buxton 1938, Lolió et al. 1975, Donaldson 1976, Gbakima 1992). There are many factors related to the host that can be associated to head lice prevalence: race, age group, sex, social-economical conditions and hair characteristics (Sinniah et al. 1981, Arene \& Ukaulor 1985, Chunge 1986). Overcrowded living conditions and the arising of resistance to insecticides have contributed to the increase of head lice in the last few years (Linardi et al 1988, Pollack et al. 1999, Lee et al. 2000).

Head lice should be better investigated regionally because its prevalence may vary according to the social situation, genetic and cultural characteristics of a population. Because of this, children attending day care centres, public urban and rural schools in the municipality of Uberlândia, State of Minas Gerais, were examined for head lice infestation. The objective of this study was to determine whether factors such as age group, sex, race, hair characteristics as well as children's home localization (rural or urban area) influence the distribution of head lice in the children and youth of Uberlândia.

+Corresponding author. Fax: +55-34-218.2333 E-mail: jmendes@ufu.br

Received 25 June 2001

Accepted 19 September 2001

\section{MATERIALS AND METHODS}

The municipality of Uberlândia is located in the western part of the State of Minas Gerais at $48^{\circ} 17^{\prime} 19^{\prime \prime} \mathrm{W}$ and $18^{\circ} 55^{\prime} 23^{\prime \prime} \mathrm{S}$. There are 487,887 habitants residing in the urban perimeter and 12,208 in the rural areas (IBGE 2000).

Children from 11 public institutions, including three day care centres, four public urban schools and four public rural schools in Uberlândia, were examined from November 1996 to March 2000 for infestation of $P$. capitis. Choice criteria of the investigated institutions was its location in the municipality (downtown, outskirts and rural area).

Previous to study initiation, parents or legal guardians of the children signed a consent form. The project was approved by the Ethics Committee of Uberlândia's Federal University (UFU) in Uberlândia.

Exams consisted of visual inspections of children's heads for $3 \mathrm{~min}$, paying special attention to the neck and behind the ears with the help of hair manipulation (Chunge 1986). Children whose hair had at least one of the developing stages of $P$. capitis, including only nit residues, were considered positive. After each exam, an individual form with child's name, age sex, skin colour (black or non black) and hair characteristics: size, type, colour, density, and thickness as well parents' or legal guardians' profession was filled in. Hairs classification according to its characteristics was done from ocular evidences after preliminary research training. Training consisted in visual classification and later confirmation of evidences with the auxiliary of ruler, light microscopy and scanning electron microscopy. Hairs were classified as straight, wavy or curly in relation to type. Regarding colour, hairs were considered fair (blond and redheaded) and dark (brown and black). For thickness, thin and thick were considered. Visual evidences of hair density were confirmed counting hairs on one $\mathrm{cm}^{2}$ of delimitated scalps' areas. Hairs density on the scalp was divided into high and low. For length, hairs were classified as short ( 0 to $3 \mathrm{~cm})$, medium $(<3 \leq 10$ 
$\mathrm{cm})$ and long (> $10 \mathrm{~cm})$. Hairs samples of black and nonblack persons were analyzed by scanning electron microscopy microscope to determine their respective forms.

The social-economical profile of the clientele from each institution was inferred in regard to their parents' or legal guardians' professions.

To compare the means of proportions of infested children from urban and rural institutions, data were first transformed into angular arc-sen ( $\mathrm{p}^{\prime}=\operatorname{arc}$. sen $\left.\sqrt{ } \mathrm{p}^{\prime}\right)$. The $t$ test was then applied. In cases in which, using $\chi^{2}$ test, significant differences between more than two proportions were found, data were then submitted to angular transformation and afterwards to Tukey-type multiple comparisons test (Zar 1999). For all statistical analyses, a significance level of $0.05 \%$ was adopted.

\section{RESULTS}

The analysis and measurements of hair samples by light microscopy and scanning electron microscopy indicated that hairs classified as thin presented average thickness' of $82.9 \mu \mathrm{m}$ and those considered as thick, averaged $98.9 \mu \mathrm{m}$. Scalps with high and low hairs density presented averages of 147 and 93 hairs $/ \mathrm{cm}^{2}$, respectively. Black and non-black persons' hairs presented respectively, oval and round shapes.

A $35 \%$ prevalence rate of head lice was found on the 884 children examined from the 11 institutions. In 50 (16.2\%) of the 309 positive children, only egg residues were found, whereas in the other 259 children, at least one of the lived (viable) instars of development was observed. Head lice distribution encountered in urban and rural institutions was $33.3 \%$ and $36.7 \%$, respectively. No statisti-

\section{TABLE I}

Head lice in children attending day care centres and public urban and public rural schools in Uberlândia, State of Minas Gerais, Brazil

\begin{tabular}{lccl}
\hline Institutions & No. examined & No. of infested (\%) \\
\hline Urban schools & 49 & $25(51)$ & $\mathrm{B}^{a}$ \\
I & 60 & $15(25)$ & $\mathrm{C}, \mathrm{E}$ \\
II & 99 & $38(38.4)$ & $\mathrm{A}, \mathrm{B}$ \\
III & 38 & $1(2.6)$ & $\mathrm{D}$ \\
IV & 49 & $18(36.7)$ & $\mathrm{A}, \mathrm{B}$ \\
V & 76 & $12(15.7)$ & $\mathrm{C}$ \\
VI & 88 & $44(50)$ & $\mathrm{B}$ \\
$\quad$ VII & 459 & $153(33.3)$ & \\
\hline Sub-total & & & \\
\hline Rural schools & 96 & $36(37.5)$ & $\mathrm{A}, \mathrm{B}, \mathrm{E}$ \\
VIII & 102 & $37(36.2$ & $\mathrm{A}, \mathrm{E}$ \\
IX & 127 & $49(38.5)$ & $\mathrm{A}, \mathrm{B}$ \\
X & 100 & $34(34)$ & $\mathrm{A}, \mathrm{E}$ \\
$\quad$ XI & 425 & $156(36.7)$ & \\
\hline Sub-total & 884 & $309(35 \%)$ & \\
\hline Total & & &
\end{tabular}

I to III: day care centres; IV to VII: urban schools; $a$ : prevalence rates that have different letters are statistically different among each other by Tukey-type test at the $5 \%$ of significance level.
TABLE II

Head lice in children attending day care centres and public urban and public rural schools in Uberlândia, State of Minas Gerais, Brazil, according to different sexes, race and age groups

\begin{tabular}{lcccc}
\hline & $\begin{array}{c}\text { No. of } \\
\text { examinations }\end{array}$ & $\begin{array}{c}\text { No. of } \\
\text { infestations }\end{array}$ & $\begin{array}{c}\text { Prevalence } \\
(\%)\end{array}$ & Significance \\
\hline Sex & & & & \\
$\quad$ Male & 443 & 101 & 22.7 & $\mathrm{~A}^{a}$ \\
Female & 441 & 208 & 47.1 & $\mathrm{~B}$ \\
Race & & & & \\
$\quad$ Black & 166 & 67 & 40.3 & $\mathrm{~A}^{a}$ \\
Non-black & 718 & 242 & 33.7 & $\mathrm{~B}$ \\
Aged & & & & \\
$0-3$ & 116 & 35 & 30.8 & $\mathrm{~A}^{a}$ \\
$4-6$ & 396 & 128 & 32.3 & $\mathrm{~A}$ \\
$7-9$ & 258 & 95 & 36.8 & $\mathrm{~A}, \mathrm{~B}$ \\
$10-12$ & 97 & 44 & 45.3 & $\mathrm{~B}$ \\
$13-15$ & 17 & 7 & 41 & A, B \\
\hline
\end{tabular}

$a$ : prevalence rates that have different letters, for each analyzed factor, are statistically different among each other by Tukeytype test at the $5 \%$ of significance level.

cal difference was found between the two values $\left(\mathrm{t}_{0.05}\right.$ (2), $9=0.6770)$. However, when rates encountered in each one of the institutions were compared, independent of their localization (rural or urban), significant differences were detected among them $\left(\mathrm{x}^{2}{ }_{0.05(10)}=992.691\right)$. Results from the Tukey-type test showed significant differences mainly between rates observed in the urban institutions (Table I).

TABLE III

Head lice in children attending day care centers and public urban and public rural schools in Uberlândia, State of Minas Gerais, Brazil according to hair characteristics

\begin{tabular}{|c|c|c|c|c|}
\hline & $\begin{array}{c}\text { No. of } \\
\text { examinations }\end{array}$ & $\begin{array}{c}\text { No. of } \\
\text { infestations }\end{array}$ & $\begin{array}{c}\text { Prevalence } \\
(\%)\end{array}$ & Significance \\
\hline \multicolumn{5}{|l|}{ Hair colour } \\
\hline Dark & 741 & 266 & 36.3 & $\mathrm{~A}^{a}$ \\
\hline Fair & 143 & 43 & 30.1 & B \\
\hline \multicolumn{5}{|c|}{ Hair density } \\
\hline Low & 251 & 89 & 35.4 & $\mathrm{~A}^{a}$ \\
\hline High & 633 & 220 & 34.7 & A \\
\hline \multicolumn{5}{|c|}{ Hair thickness } \\
\hline Thin & 693 & 234 & 33.7 & $\mathrm{~A}^{a}$ \\
\hline Thick & 191 & 75 & 39.2 & A \\
\hline \multicolumn{5}{|c|}{ Type of hair } \\
\hline Curly & 265 & 78 & 29.5 & $\mathrm{~A}^{a}$ \\
\hline Wavy & 342 & 145 & 44.7 & $\mathrm{~B}$ \\
\hline Straight & 277 & 86 & 31 & A \\
\hline \multicolumn{5}{|c|}{ Length of hair } \\
\hline Short & 453 & 109 & 24 & $\mathrm{~A}^{a}$ \\
\hline Medium & 258 & 102 & 39.5 & $\mathrm{~B}$ \\
\hline Long & 173 & 98 & 52.6 & $\mathrm{C}$ \\
\hline
\end{tabular}

$\bar{a}$ : prevalence rates that have different letters, for each analyzed factor, are statistically different among each other by Tukeytype test at the $5 \%$ of significance level. 
When head lice distribution was compared according to age group and independent of children's origin, an increase in the prevalence rates with the increase of age, up to 12 years old was observed (Table II).

Head lice distribution compared by sex and race showed significant differences $\left(\mathrm{x}^{2}{ }_{0.05(1)}=46.48 ; \mathrm{x}_{0,05}^{2}\right.$ $(1)=3.86)$ (Table II). The length of hair also was shown as an important factor influencing the distribution of head lice $\left(\mathrm{x}^{2}{ }_{0.05(2)}=50.04\right)$. Children with long, wavy and dark hairs presented greater prevalence rates than those with other hair types (Table III). On the other hand, both density and thickness were not shown to be associated to the parasite distribution (Table III).

Analysis of clienteles' social-economical profile indicated that children attending day care centres and rural schools were in the majority from families of lower social economical level (hard labour workers). Clientele from urban schools were more heterogeneous and came from families with different social economical backgrounds. Parents or legal guardians professions from this group were diverse including, liberal professionals, small business owners and hard labour workers.

\section{DISCUSSION}

The prevalence rate encountered in the present work (35\%, Table I) is among the highest observed in different parts of the world, when compared with the $49.7 \%$ in Ghana (Kwaku-Kpikpi 1982), the $48.7 \%$ in France (Courtiade et al. 1993) or the $33.7 \%$ in Australia (Speare \& Buettner 1999). It should be emphasised that high rates were found in institutions located in the central regions, outskirts of the city as well as in the rural area. The main factor that influenced the clienteles' social-economical profile from the urban institution seems to be the gratuity of education and or children assistance provided by the institutions and not their location in the urban region.

Studies on head lice in populations with different social-economical levels have encountered significant differences between prevalence rates in different populations and regions (Lolió et al. 1975, Ewasechko 1981, Kwaku-Kpikpi 1982). However, the finding of both low and high rates of head lice prevalence in children from countries with different levels of social-economical development indicates that this factor also can present different degrees of importance in head lice distribution in some regions (Hoffmann 1983, Chouela et al. 1997). This is partially due to the existence of many factors influencing its prevalence (Arene \& Ukaulor 1985). In some regions, association to some factors is predominant in relation to others that in turn may be epidemiologically more important in other ones. Results obtained in the present work on head lice distribution in black and non-black children (Table II) are conflicting with results from other studies (Ashcroft 1969) and strengthen the hypothesis that associated factors are region-dependent. These results seem also be conflicting with the ones obtained by Linardi et al. (1989) in Belo Horizonte, State of Minas Gerais as well. Nevertheless, those authors categorized the children as whites and brunets (including dark brunets, mulattos and blacks) and now the children were separated into blacks and non-blacks (including dark brunets, brunets and whites). Lowers head lice prevalences generally encountered in blacks would be due to the differences in shape of hair between races (Ashcroft 1969, Chunge 1986). Results found in the present study indicate that, as other studied factors, the shape of hair is not preponderant in the installation of head lice in the studied population. The finding of a higher prevalence rate in black children may be due to the surpassing of social and cultural factors, which would be increasing the susceptibility of this group to head lice, to the factor hair shape, that would be decreasing their susceptibility to head lice.

The fact that the children with curly hair - category where black children were also included - have presented lower prevalence rate than those with other types of hair seems at first sight, conflicting with results obtained with the factor hair shape. However, many non-black children presented both short and curly hairs and were included into this group. The analyses indicated that the prevalence rate of this ectoparasite in children with short hairs was lower than in those with other lengths of hair (Table III). This may be due to earlier and easier diagnosis and control of head lice in children with short hairs. Therefore, the lower prevalence rate of head lice found in children with curly hairs was also associated to their hairs size.

Differences in the head louse distribution rates between age groups - although non-significant between some compared age groups in this study - and between sexes are supported by many studies (Petrelli et al. 1980, Sinniah et al. 1981, Sarov et al. 1988, Speare \& Buettner 1999). These differences may be associated with behavioural variations in the different age groups and sexes (Courtiade et al. 1993, Speare \& Buettner 1999). The predominance of long hairs in females is another factor associated to higher prevalence of pediculosis in this group (Sinniah et al. 1981, Linardi et al. 1989, Mumcuoglu et al. 1990).

The absence of significant differences between the prevalence rates of pediculosis in schoolchildren from rural and urban area (Table I) are in agreement with Chunge (1986). Nevertheless, other surveys have verified significant differences between head lice distribution found in urban and rural schoolchildren (Donaldson 1976, Hoffmann 1983, Ogunridade \& Oyejide 1984). Finally, the absence of significant differences between the prevalence rates of head lice in children from rural institutions may be indicative of a greater homogeneity of this group, from the epidemiological point of view, when compared with children from urban institutions. As a consequence, common control measures would be proposed for this ectoparasite for the former institutions and the consequent necessity to adopt differentiated head lice control measures for some of the latter ones.

\section{REFERENCES}

Arene FOI, Ukaulor AL 1985. Prevalence of head louse (Pediculus capitis) infestation among inhabitants of Niger Delta. Trop Med Parasitol 3: 140-142.

Ashcroft MT 1969. Racial differences in Pediculus h. capitis infestation in Guyana. Trans R Soc Trop Med Hyg 63: 547. Buxton PA 1938. Studies on population of head lice (Pediculus 
humanus capitis: Anoplura) I. Parasitology 30: 85-110.

Chouela E, Abeldano A, Cirigliano M, Ducard M, Neglia V, Forgia M, Colombo A 1997. Head louse infestations: epidemiologic survey and treatment evaluation in Argentinian schoolchildren. Int J Dermatol 36: 819-825.

Chunge RNA 1986. Study of head lice among primary schoolchildren in Kenya. Trans R Soc Trop Med Hyg 80: 42-46.

Courtiade C, Labrieze C, Fontan I, Taieb A, Maleville J 1993. Pediculosis capitis: a questionare survey in 4 schools of the Bordeux Academy 1990-1991. Ann Dermatol Venereol 120: 363-368.

Donaldson RJ 1976. The head louse in England: Prevalence amongst schoolchildren. $J R$ Soc Health 96: 55-57.

Ewasechko CA 1981. Prevalence of head lice (Pediculus humanus capitis) among children in a Rural, Central Alberta School. Can J Public Health 72: 249-252.

Gbakima AA 1992. The head louse in Sierra Leone: an epidemiological study among school children, in the Njala area. West Afr J Med 11: 165-171.

IBGE 2000. Anuário Estatístico do Censo de 2000, Uberlândia, $M G$, Instituto de Geografia e Estatística, Rio de Janeiro.

Hoffmann G 1983. Epidemiology and control of pediculosis capitis infestation in the Federal Republic of Germany. $J R$ Soc Health 103: 378-381.

Kwaku-Kpikpi JE 1982. The incidence of the head louse (Pediculus humanus capitis) among pupils of two schools in Accra. Trans R Soc Trop Med Hyg 76: 378-381.

Lee SH, Yoon K-S, Williamson MS, Goodson SJ, Takano-Lee M, Edman JD, Devonshire AL, Clark JM 2000. Molecular analysis of $k d r$-like resistance in permethrin-resistant strains of head lice, Pediculus capitis. Pestic Biochem Physiol 66: 130-143.

Linardi PM, Botelho JR, Maria M 1988. Crendices e falsos conceitos que dificultam ações profiláticas contra o piolho e a pediculose "capitis". J Pediatria 64: 248-255.

Linardi PM, Maria M, Botelho JR, Cunha HC, Ferreira JB
1989. Pediculose capitis: prevalência em escolares da rede municipal pública de Belo Horizonte, Minas Gerais, Brasil. Mem Inst Oswaldo Cruz 84: 368-372.

Lolió M, Schenone H, Saavedra R, Banda R, Villaroel F, Rojo M, Subiabre V, Arias B, Rojas A, Vicent P, Grinspun M, Sudy E, Canello J, Sepulveda A, Salas L 1975. Prevalência actual de sarna y pediculosis capitis en alumnos de la enseñanza básica de Santiago, Chile. Bol Chil Parasitol 30 : 50-53.

Madureira PR 1991. Pediculosis and ethnic groups. Int J Dermatol 30: 524.

Muncuoglu KY, Miller J, Gofin R 1990. Epidemiological studies on head lice infestation in Israel. Int J Dermatol 29: 502-506.

Ogunrinade AF, Oyejide CO 1984. Pediculosis capitis among rural and urban schoolchildren in Nigeria. Trans $R$ Soc Trop Med Hyg 78: 590-592.

Petrelli G, Majori G, Maggini M, Taggi F, Maroli M 1980. The head louse in Italy: an epidemiological study among schoolchildren. J R Soc Health 100: 64-66.

Pollack RJ, Kiszewski A, Armstrong P, Hahn C, Wolfe N, Rahman HA, Laserson K, Telford III SR, Spielman A 1999. Differential permethrin susceptibility of head lice sampled in the United States and Borneo. Arch Pediatr Adolesc Med 153: 969-973.

Sarov B, Neumann L, Herman Y 1988. Evalution of an intervention program for head lice infestations in school children. Pediatr Infect Dis 7: 176-179.

Sinniah B, Sinniah D, Rajeswari B 1981. Epidemiology of Pediculus humanus capitis infestation in Malaysian school children. Am J Trop Med Hyg 30: 734-738.

Speare R, Buettner PG 1999. Head lice in pupils of a primary school in Australia and implications for control. Int $J$ Dermatol 38: 285-290.

Zar JH 1999. Bioestatistical Analysis, 4th ed., Prentice Hall INC, New Jersey, 718 pp. 